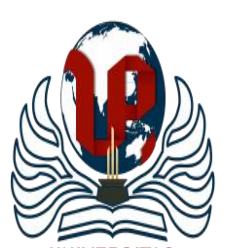

UNIVERSITAS

Jurnal Basicedu Volume 4 Nomor 4 Tahun 2020 Halaman 1074-1083

JURNAL BASICEDU

Research \& Learning in Elementary Education

https://jbasic.org/index.php/basicedu

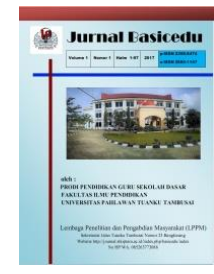

\title{
Problem-Solving Method: The Effectiveness of The Pre-service Elementary Education Teacher Activeness in The Concept of Physics Content
}

\author{
Bramianto Setiawan ${ }^{1}$, Reza Rachmadtullah ${ }^{2}$, Vina Iasha ${ }^{3}$ \\ Department of Primary Education, Universitas PGRI Adi Buana, Indonesia ${ }^{1,2}$ \\ Department of Postgraduate Elementary Education, Universitas Negeri Jakarta, Indonesia ${ }^{3}$ \\ E-mail: $\underline{\text { bramianto@gmail.com }}{ }^{1}$ rezarachmadtullaheza@ gmail.com ${ }^{2}$ and vina.iasha@gmail.com ${ }^{3}$
}

\begin{abstract}
Abstrak
Penelitian ini bertujuan untuk mengetahui efektivitas metode problem-solving terhadap keaktifan calon guru Pendidikan Guru Sekolah Dasar. Penelitian ini menggunakan penelitian eksperimental dengan desain faktorial 2x2 dimana kelas eksperimen menggunakan metode problem-solving dan kelas kontrol menggunakan metode ceramah. Data untuk penelitian ini dikumpulkan dalam 2 cara, data diperoleh dengan lembar pengamatan kegiatan belajar dan tes kemampuan kognitif siswa. Dari data tersebut, terlihat bahwa metode problem-solving dapat meningkatkan aktivitas belajar siswa, terutama dalam pembelajaran fisika. Selain itu, interaksi antara masing-masing variabel dicari menggunakan uji Analisis Varians (ANOVA). Dari hasil tes menunjukan bahwa hipotesis pertama ditolak yang menunjukkan bahwa ada perbedaan efek antara metode pembelajaran pada kemampuan kognitif siswa. Hipotesis kedua juga ditolak yang berarti bahwa ada perbedaan efek antara kategori kegiatan belajar siswa pada kemampuan kognitif siswa. Di sisi lain, hipotesis ketiga diterima yang menunjukkan bahwa tidak ada interaksi antara penggunaan metode pembelajaran dan kegiatan belajar siswa pada kemampuan kognitif siswa.
\end{abstract}

Kata kunci: metode problem-solving, calon guru, aktivitas belajar siswa, ANOVA

\section{Abstract}

This research aim is to know the effectiveness of the problem-solving method on the activeness of the preservice elementary education teacher. This research used experimental research with a $2 \times 2$ factorial design where the experiment class used the problem-solving method and the control class used traditional lecturemethod. Data for this research was collected in 2 ways, the data was obtained by the observation of student's learning activities and the test of the student's cognitive ability. From those data, it shows that problemsolving methods can increase students' learning activities, especially in physics learning. Moreover, the interaction between each variable was searched using the Analysis of Variance (ANOVA) test. The result of the test, the first hypothesis was rejected that indicates that there was a difference in effect between learning methods on the students' cognitive ability. The second hypothesis was also rejected which means that there was a difference in effect between the category of the students' learning activities on the students' cognitive ability. On the other hand, the third hypothesis was accepted that indicates that there is no interaction between the use of learning methods and students' learning activities on the students' cognitive ability.

Keyword: problem-solving method, pre-service teacher, students learning activities, ANOVA

Copyright (c) 2020 Bramianto Setiawan, Reza Rachmadtullah, dan Vina Iasha

Corresponding author :

Address : Jl. Dukuh Menanggal no.14, kec. Gayung, Kota Surabaya

Email : sbramianto@gmail.com

ISSN 2580-3735 (Media Cetak)

Phone : 08562805580

ISSN 2580-1147 (Media Online)

DOI: https://doi.org/10.31004/basicedu.v4i4.484 
1075 Problem-Solving Method: The Effectiveness of the Pre-service Elementary Education Teacher Activeness in the Concept of Physics content-Bramianto Setiawan, Reza Rachmadtullah, Vina Iasha DOI: https://doi.org/10.31004/basicedu.v4i4.484

\section{INTRODUCTION}

Along with the fast development of science and technology, it must be realized that improving the quality of human resources in Science, Technology, Engineering, and Technology (STEM) is very necessary. Education design that includes STEM knowledge is one important aspect that plays a role to improve the quality of human resources (Peercy and Svenson 2016). There are many ways to improve education quality that can increase the STEM knowledge i.e. development of curriculum (Kuan et al. 2016; Rowe and Zegwaard 2017), applying technology in the field of education (Arista and Kuswanto 2018; Setiawan et al. 2017), using the appropriate learning method in the class (Dywan and Airlanda 2020; Jannah and Mudjiran 2019), the development of instrument assessment (Merta Dhewa et al. 2017; Simarmata, Wardani, and Prasetyo 2019), and others. But, the use of the learning methods is one of a good way to improve education quality because it is directly related to human resources (students). By giving a good learning method in the class, students will easily understand the concept, especially in the physics field.

The traditional lecture-method from the teacher can give large information to the student but it also makes passive learning result such as low motivation in the learning process, low understanding of basic knowledge, and short memory of the course material (Goldstein 2016). So, the alternative method is needed to solve this problem. The problem-solving method can be an alternative method to change the traditional lecture-method that focused on the student based on constructively learning in education especially in physics concepts (Savery 2015). In the problemsolving method, the students both individually and cooperatively are required to solve relevant problems that can enhance their knowledge (Dolmans et al. 2016; Fidan and Tuncel 2019). So, this method can stimulate the student's creative thinking ability and make the learning process in the classroom more relevant to real-life (Fidan and Tuncel 2019).

Some researchers were used problemsolving methods in the learning process. Prahari et. al. used the problem-solving method in physic learning. They concluded that this model could effectively improve the self-confidence of the students in physics (Prahani et al. 2018). Simamora et. al. in their research also said that the problem-solving method could improve the learning activities and problem-solving ability of the students (Simamora, Sidabutar, and Surya 2017). Jennifer et. al. used the problem-solving method in their class. They concluded that by integrating problem-solving into the curriculum, students could produce higher quality solutions than before and had higher scores on conceptual and problem-solving measures (Docktor et al. 2015). Argaw et. al. in their research result report that the problem-solving method is a good alternative method in the learning process to increase academic achievement students (Argaw et al. 2016). Moreover, the problem-solving method could generate interest in the STEM career in the future (LaForce, Noble, and Blackwell 2017).

In the learning process, students' learning activities are also one of the important aspects that 
must be considered by the teacher to get maximum results in the class. Students' learning activities can be defined as a series of physical and mental student activities in following the teaching and learning process to develop the students' potential (Am 2011). Suitable learning methods can increase student learning activities so it becomes very memorable and easy to remember. This fact can be caused that the learning process through the thought process, processing data, and then issued again in different forms, such as expressing opinions or carrying out tasks. Students with high learning activities have higher both skill and knowledge abilities than other students (Watson et al. 2017).

Based on the observation result, the authors obtained information that the traditional lecturemethod gives low motivation, especially in the students' learning activities in the class. So, the problem-solving method is an alternative method that authors use to know the effects of the Problem-solving method on the activeness especially in for the pre-services elementary school education teacher in a physics concept.

\section{METODE}

The variables of this research were the learning methods and students' learning activities. The learning method variables were divided into problem-solving and traditional lecture-method and the students' learning activities variables were divided into high and low categories. The classification of students' learning activities was done by separating the maximum value of observation data into two levels. The determination of students' learning activities categories is shown in table 1 .

Table 1. Determination of Student Learning Activity Categories

\begin{tabular}{ccc}
\hline No. & $\begin{array}{c}\text { Students' learning } \\
\text { activities score }\end{array}$ & Category \\
\hline 1. & $21 \leq$ Skor $\leq 40$ & $\begin{array}{c}\text { High students' } \\
\text { learning activities } \\
\text { Low students' } \\
\text { learning activities }\end{array}$ \\
\hline 2. & $10 \leq$ Skor $\leq 20$ & \\
\hline
\end{tabular}

This research used simple factorial design $2 \times 2$ that was shown in table 2 .

Table 2. Simple Factorial Design $2 \times 2$ in This Research

\begin{tabular}{llcc}
\hline & & \multicolumn{2}{c}{$\begin{array}{c}\text { Students' Learning } \\
\text { Activities (B) }\end{array}$} \\
\cline { 3 - 4 } & High (B $\left.\mathrm{B}_{1}\right)$ & $\begin{array}{c}\text { Low } \\
\left(\mathrm{B}_{2}\right)\end{array}$ \\
$\begin{array}{l}\text { Learning } \\
\text { method } \\
\text { (A) }\end{array}$ & $\begin{array}{l}\text { Problem- } \\
\text { solving } \\
\text { method (A1) }\end{array}$ & $\mathrm{A}_{1} \mathrm{~B}_{1}$ & $\mathrm{~A}_{1} \mathrm{~B}_{2}$ \\
& $\begin{array}{l}\text { Traditional } \\
\text { lecture- } \\
\text { method (A2) }\end{array}$ & $\mathrm{A}_{2} \mathrm{~B}_{1}$ & $\mathrm{~A}_{2} \mathrm{~B}_{2}$ \\
& & & \\
\hline
\end{tabular}

The subjects of this research were all students in first-year Elementary School Teacher Education in Universitas PGRI Adi Buana Surabaya. The research samples were chosen by a random sampling method as an experiment and control class. The first class was an experiment class that used the problem-solving method and the second class was a control class that used traditional lecture-method. Both classes have been tested for similarity initially using the two-tailed ttest. The two-tailed t-test requirements are samples from populations that are normally distributed and 
homogeneous.

Data for this research was collected in 2 ways, first data was obtained by the observation of students' learning activities that including 4 categories, i.e. visual, oral, writing, and listening activities and the second was obtained by the test of the student's cognitive ability. There was 10 aspect which was used as the measurement of students' learning activities. Each aspect has a maximum value of 4 and a minimum value of 1 in the observation form. The determination of students' learning activities measurement aspect is shown in table 3 . The experiment and control class in this research have the same lesson i.e fluid static matter and the same test to obtain both students' learning activity and cognitive skill.

Table 3. Determination of Student Learning Activity Measurement Aspect

\footnotetext{
No. Students' Learning Activity Measurement Aspect

1. Asking the teacher without being appointed

2. Giving the ideas to solve the problems in the discussion

3. Answering questions asked without being invited by the teacher

4. Giving attention to the teacher while the lesson is taking place

5. Giving attention when other students give their opinions/presentations

6. Listening to the explanation from the teacher

7. Listening to the explanations of the friends who give the argue / presentations

8. Taking the notes from the teacher's explanation

9. Writing the discussion result

10. Writing the answers to the questions on the board without being appointed
}

This research also used ANOVA test that has three hypotheses, namely:

- $\mathrm{H}_{0 \mathrm{~A}}: \alpha_{\mathrm{i}}=0$ There is no difference in effect between the problem-solving method and the traditional lecture method on the students' cognitive ability.

- $\mathrm{H}_{0 \mathrm{~B}}: \beta_{\mathrm{j}}=0 \quad$ There is no difference in effect between a high and low category of the student's learning activities on the students' cognitive ability.

- $\mathrm{H}_{\mathrm{AB}}: \alpha \beta_{\mathrm{ij}}=0$ There is no interaction between the use of learning methods and students' learning activities on the students' cognitive ability.

\section{Result and Discussion}

\section{Similarity Initially Test}

Before the research began, the similarity initially of the samples using the two-tailed t-test was used to know the capability of each sample. But its test should be preceded by the normality and homogeneity test for each sample. The normality test used the Lilliefors method with a significant degree $(\alpha) 5 \%$ and the result was shown in table 4.

Table 4. The Result of The Normality Test

\begin{tabular}{lcc}
\hline \multicolumn{1}{c}{ Sample } & $\boldsymbol{L}$-observation & $\boldsymbol{L}$-table \\
\hline $\begin{array}{l}\text { Experiment } \\
\text { Class }\end{array}$ & 0.1358 & $\mathrm{~L}_{0.05 ; 31}=0.159$ \\
Control Class & 0.0858 & $\mathrm{~L}_{0.05 ; 32}=0.156$ \\
\hline
\end{tabular}

Based on the calculation, $L$-observation of each class have a lower value than $L$-table so the $L$ observation value was not meet in the critical region of the normal test. It can be concluded that the sample both experiment and control class were normally distributed. On the other hand, the homogeneity test result using the Bartlett method 
shows that $X^{2}$ hitung has had a lower value than $X_{\text {table }}$ $\left(X_{\text {hitung }}^{2}=3.063<X_{\text {table }}^{2}=3.841\right)$. This indicates that both samples have come from homogeneous populations.

On the other hand, the similarity of both the level of knowledge and skills of the experimental and control classes was seen from the UTS scores of the two classes. Both of these classes have almost the same UTS values, 37.17 for the experimental class, and 32.7 for the control class.

\section{Students' Learning Activities}

The students' activities data that were collected using an observation form was shown in Table 5. Based on the data, the experiment class has an average value of 22.58 , the maximum value of 30.20 , and the minimum value of 26.20 . On the other hand, the control class has an average value of 19.73 , the maximum value 26.20 , and the minimum value of 15.33 .

Table 5. Students Learning Activities Data

\begin{tabular}{lccccc}
\hline \multicolumn{1}{c}{ Sample } & $\begin{array}{c}\text { Numbe } \\
\text { r of } \\
\text { samples }\end{array}$ & Max & Min & $\begin{array}{c}\text { Aver } \\
\text { age }\end{array}$ & $\begin{array}{c}\text { Std. } \\
\text { dev }\end{array}$ \\
\hline $\begin{array}{l}\text { Experiment } \\
\text { class }\end{array}$ & 31 & 30.2 & 17.8 & 22.64 & 3.47 \\
Control class & 32 & 26.2 & 15.3 & 19.73 & 3.26 \\
\hline
\end{tabular}

The data for each category high and low student learning activities in both experiment and control class was shown in figure 1. Figure 1 shows that the experiment class using the problemsolving method has a higher number of students' activeness samples than the control class. This indicates that the problem-solving method is the right method to use in the learning process for pre- service elementary education teachers due to the increase in students learning activities. It has the same result as Simamora et. al that the problemsolving method could increase the students' learning activities (Simamora et al. 2017). The increasing of the learning students' activities occurs due to the curiosity of the student to solved the physics phenomena. This curiosity makes the student want to know how the phenomena could occur.
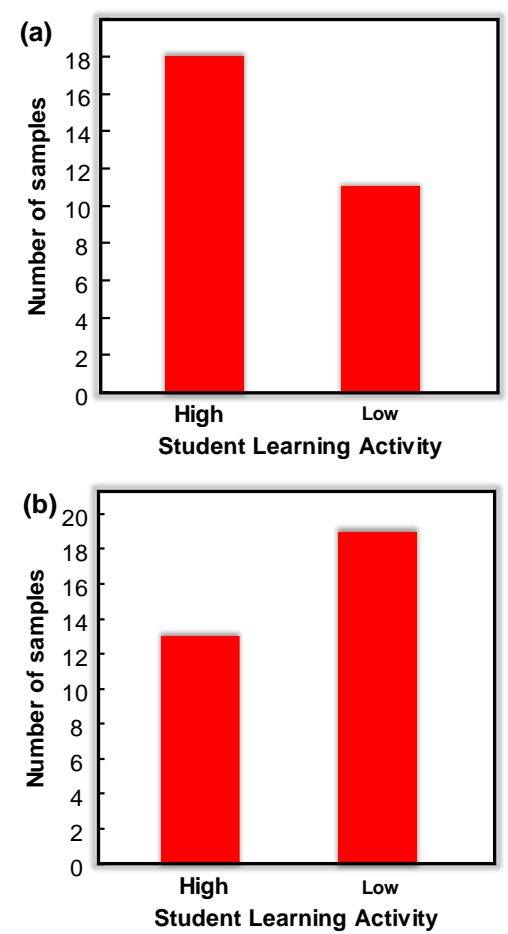

Figure 1. Graph of Each Category in Students' Learning Activities: (a) Experiment Class and (b) Control Class

On the other hand, the students' learning activities are also divided into gender categories (male and female). The data for each gender categories were shown in figure 2 . 

Activeness in the Concept of Physics content- Bramianto Setiawan, Reza Rachmadtullah, Vina Iasha DOI: https://doi.org/10.31004/basicedu.v4i4.484

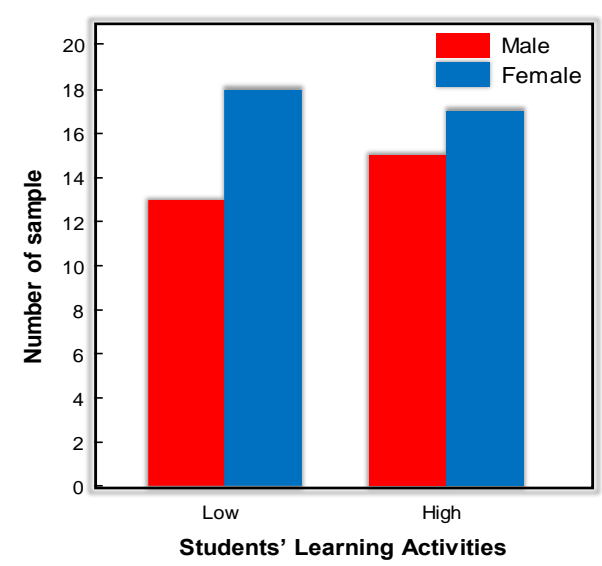

Figure 2. Graph of Each Category in Students' Learning Activities That Were Divided Into Gender

Figure 2 shows that the students' learning activities in pre-service elementary education teachers in PGRI Adi Buana Surabaya University have dominated by the female students. In this sample also show that the female students were more curiosity in the physics learning than male students. The difference of this value caused by the topic interest both female and male students (Chen, Yang, and Hsiao 2016).

\section{Students Cognitive Ability}

The students' cognitive ability was gotten by testing of the student using multiple-choice questions. The data from cognitive ability were collected using multiple-choice questions that were shown in Table 6.

Table 6. The Summary of The Students Testing Results.

\begin{tabular}{lcccc}
\hline Sample & $\begin{array}{c}\text { Number } \\
\text { of } \\
\text { Samples }\end{array}$ & $\begin{array}{c}\text { Max. } \\
\text { Value }\end{array}$ & $\begin{array}{c}\text { Min. } \\
\text { Value }\end{array}$ & $\begin{array}{c}\text { Avera } \\
\text { ge }\end{array}$ \\
\hline $\begin{array}{l}\text { Experiment } \\
\text { Class }\end{array}$ & 31 & 52 & 16 & 34.97 \\
Control & 32 & 48 & 8 & 26.30 \\
\hline
\end{tabular}

Class

The distribution of the students testing results in both experiment and control classes was shown in figure 3.
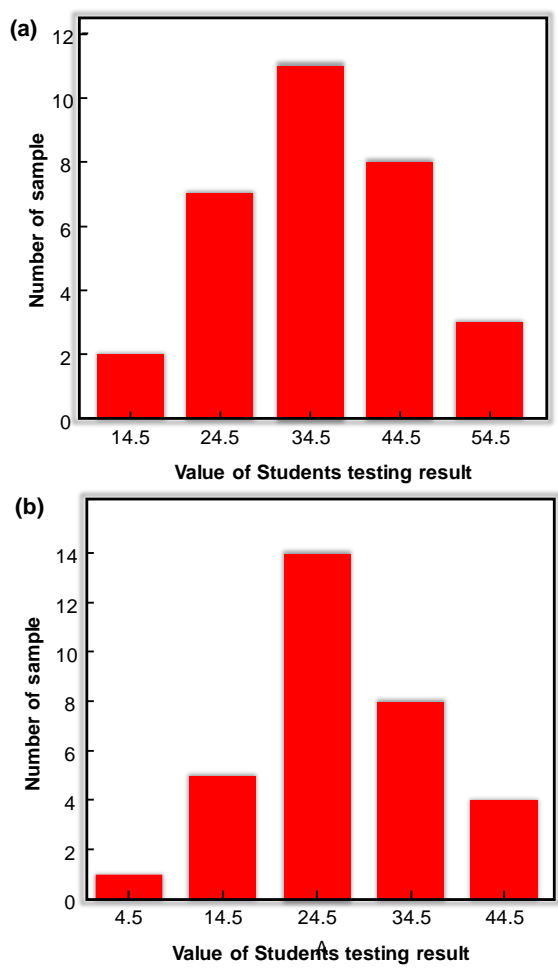

Figure 3. Graph of The Students' Testing Result Distribution: (a) Experiment Class and (b) Control Class

Figure 3 shows that the testing result has a normal distribution for each sample class, both experiment, and control class. But the experiment class has a higher value for the testing result than the control class. The experiment class shows a testing value range from 14.5 to 54.5 while the control class shows a testing value range from 4.5 to 44.5. This data presents that the problemsolving method also can increase the knowledge of the pre-service elementary education teacher students. Its result also has the same result as 

Activeness in the Concept of Physics content-Bramianto Setiawan, Reza Rachmadtullah, Vina Iasha DOI: https://doi.org/10.31004/basicedu.v4i4.484

Cheng et.al. research (Cheng, She, and Huang 2017). With the problem in the learning process, students will explore to get the answers to these problems. This activity makes students more easily recorded the physics concept than they only listening from the teacher.

\section{Hypothesis Testing Results}

The hypothesis research was tested using a two-way analysis of variance (ANOVA) with unequal cell contents. Student achievement scores in the experiment class and control class are grouped according to the category of student learning activities from the results of observation. Based on the statistic calculation using a significance level of $5 \%$, the result of hypothesis testing is shown in table 7 .

Table 7. The Calculation Result Of ANOVA with Unequal Cell Contents

\begin{tabular}{lccccc}
\hline \multicolumn{1}{c}{ Category } & JK & $\mathbf{d k}$ & $\mathbf{R K}$ & $\mathbf{F}_{\text {obs }}$ & $\mathbf{F}_{\boldsymbol{\alpha}}$ \\
\hline $\begin{array}{l}\text { Learning } \\
\text { Method(A) }\end{array}$ & 986.955 & 1 & 986.9 & 11.2 & 4,08 \\
$\begin{array}{l}\text { Students' } \\
\text { Learning }\end{array}$ & 590.556 & 1 & 590.5 & 6.74 & 4,08 \\
$\begin{array}{l}\text { Activities (B) } \\
\text { Interaction }\end{array}$ & 274.673 & 1 & 274.6 & 3.13 & 4,08 \\
(AB) & & & 56 & 7 & \\
Error & 5164 & 59 & 87,53 & & \\
& & & 52 & & \\
Total & 6414.66 & 62 & & & \\
& 0 & & & & \\
\hline
\end{tabular}

Description:

JK : The sum of square

$\mathrm{dK}:$ The degree of freedom

RK : Average square

Fobs: F observation

$\mathrm{F} \alpha \quad$ : F table

The table shows that the first hypothesis in which interaction learning method on students' cognitive ability has $\mathrm{F}_{\text {obs }}$ value 11.275. This value is a higher value than $\mathrm{F}_{\text {table }}\left(\mathrm{F}_{\alpha}\right)$. It indicates that there was a difference in effect between the problem-solving method and the traditional lecture method on the students' cognitive ability. The difference in the effect learning method was shown by the average of testing results where the problem-solving method has a higher result than the traditional lecture method as the present above. The problem-solving method made the students more active in the learning process and could prove the truth of physics theory. While the traditional lecture method made the students less active to find their physics concept because the concept was obtained by seeing the demonstration from the teacher. So, the student mastery of the concept was less than the problem-solving method.

The second hypothesis which interaction students' learning activities category on students' cognitive ability also has a higher value of $F_{o b s}$ (6.747) than $F_{\text {table }}(F 4.08)$. It means that there was a difference in effect between the high and low category of the students' learning activities the students' cognitive ability. Students who have high learning activities have a strong desire to be active in the learning process. While the students who have low learning activities will have low awareness to be active in the learning process. The activeness level of the students given an effect on knowledgeability. It is proven by the result of the testing result which the active students have higher testing results than others.

On the other hand, the third hypothesis has a lower value of $\mathrm{F}\left(\mathrm{F}_{\mathrm{obs}}\right)$ than $\mathrm{F}_{\text {table }}\left(\mathrm{F}_{\alpha}\right)$. It indicates 
that there is no interaction between the use of learning methods and students' learning activities on the students' cognitive ability. The result shows that the learning method and the students learning activities give their influence on the students' knowledgeability. Furthermore, these results can occur due to internal or external factors.

\section{Conclusion}

In this research, the data result shows that the problem-solving method is the right method that can increase students' learning activities and cognitive ability. The ANOVA test was also used to know the interaction of each variable. Based on the statistic calculation, the first hypothesis was rejected that indicates that there was a difference in effect between the problem-solving method and the traditional lecture method on the students' cognitive ability. The second hypothesis was also rejected which means that there was a difference in effect between the high and low category of the students' learning activities the students' cognitive ability. On the other hand, the third hypothesis was accepted that indicates that there is no interaction between the use of learning methods and students' learning activities on the students' cognitive ability.

\section{References}

Am, Sardiman. 2011. "Interaksi Dan Motivasi Belajar Mengajar." Jakarta: Raja Grafindo Persada.

Argaw, Aweke Shishigu, Beyene Bashu Haile, Beyene Tesfaw Ayalew, and Shiferaw Gadisa Kuma. 2016. "The Effect of Problem Based Learning (PBL) Instruction on Students' Motivation and Problem
Solving Skills of Physics." Eurasia Journal of Mathematics, Science and Technology Education 13(3):857-71.

Arista, Fitra Suci, and Heru Kuswanto. 2018. "Virtual Physics Laboratory Application Based on the Android Smartphone to Improve Learning Independence and Conceptual Understanding." International Journal of Instruction 11(1):1-16.

Chen, So-Chen, Stephen J. H. Yang, and ChiaChang Hsiao. 2016. "Exploring Student Perceptions, Learning Outcome and Gender Differences in a Flipped Mathematics Course." British Journal of Educational Technology 47(6):1096-1112.

Cheng, Shu-Chuan, Hsiao-Ching She, and Li-Yu Huang. 2017. "The Impact of ProblemSolving Instruction on Middle School Students' Physical Science Learning: Interplays of Knowledge, Reasoning, and Problem Solving." Eurasia Journal of Mathematics, Science and Technology Education 14(3):731-43.

Docktor, Jennifer L., Natalie E. Strand, José P. Mestre, and Brian H. Ross. 2015. "Conceptual Problem Solving in High School Physics." Physical Review Special Topics-Physics Education Research 11(2):20106.

Dolmans, Diana H. J. M., Sofie M. M. Loyens, Hélene Marcq, and David Gijbels. 2016. "Deep and Surface Learning in ProblemBased Learning: A Review of the Literature." Advances in Health Sciences Education 21(5):1087-1112.

Dywan, Almahida Aureola, and Gamaliel Septian Airlanda. 2020. "Efektivitas Model Pembelajaran Project Based Learning Berbasis STEM Dan Tidak Berbasis STEM Terhadap Kemampuan Berpikir Kritis Siswa." Jurnal Basicedu 4(2):34454.

Fidan, Mustafa, and Meric Tuncel. 2019. "Integrating Augmented Reality into Problem Based Learning: The Effects on 
1082 Problem-Solving Method: The Effectiveness of the Pre-service Elementary Education Teacher Activeness in the Concept of Physics content-Bramianto Setiawan, Reza Rachmadtullah, Vina Iasha DOI: https://doi.org/10.31004/basicedu.v4i4.484

Learning Achievement and Attitude in Physics Education." Computers \& Education 142:103635.

Goldstein, Olzan. 2016. “A Project-Based Learning Approach to Teaching Physics for Pre-Service Elementary School Teacher Education Students." Cogent Education 3(1):1200833.

Jannah, Nuri Hayatul, and Mudjiran Mudjiran. 2019. "MODEL PEMBELAJARAN KOOPERATIF TIPE THINK PAIR SHARE, AKTIVITAS DAN HASIL BELAJAR PESERTA DIDIK." Jurnal Basicedu 3(4):2125-29.

Kuan, Wen-Hsuan, Chi-Hung Tseng, Sufen Chen, and Ching-Chang Wong. 2016. "Development of a Computer-Assisted Instrumentation Curriculum for Physics Students: Using LabVIEW and Arduino Platform." Journal of Science Education and Technology 25(3):427-38.

LaForce, Melanie, Elizabeth Noble, and Courtney Blackwell. 2017. "Problem-Based Learning (PBL) and Student Interest in STEM Careers: The Roles of Motivation and Ability Beliefs." Education Sciences 7(4):92.

Merta Dhewa, Kusuma, Undang Rosidin, Abdurrahman Abdurrahman, and Agus Suyatna. 2017. "The Development of Higher Order Thinking Skill (Hots) Instrument Assessment in Physics Study." IOSR Journal of Research \& Method in Education (IOSR-JRME) 7(1):26-32.

Peercy, Chavanne, and Nanette Svenson. 2016. "The Role of Higher Education in Equitable Human Development." International Review of Education 62(2):139-60.

Prahani, B. K., N. Suprapto, Lestari Suliyanah, Jauhariyah NA, and Admoko MNR. 2018. "The Effectiveness of Collaborative Problem Based Physics Learning (CPBPL) Model to Improve Student's Selfconfidence on Physics Learning." Pp.
1-6 in Journal Physics: Conference Series. Vol. 997.

Rowe, Anna D., and Karsten E. Zegwaard. 2017. "Developing Graduate Employability Skills and Attributes: Curriculum Enhancement through Work-Integrated Learning."

Savery, John R. 2015. "Overview of ProblemBased Learning: Definitions and Distinctions." Essential Readings in Problem-Based Learning: Exploring and Extending the Legacy of Howard $S$. Barrows 9:5-15.

Setiawan, B., RD Septianto, ... D. SuhendraPhysics, and Undefined 2017. 2017. "Measurement of 3-Axis Magnetic Fields Induced by Current Wires Using a Smartphone in Magnetostatics Experiments." Physics Education 52(6):065011.

Simamora, Rustam E., Dewi Rotua Sidabutar, and Edy Surya. 2017. "Improving Learning Activity and Students' Problem Solving Skill through Problem Based Learning (PBL) in Junior High School." International Journal of Sciences: Basic and Applied Research (IJSBAR) 33(2):321-31.

Simarmata, Nada Naviana, Naniek Sulistya Wardani, and Tego Prasetyo. 2019. "PENGEMBANGAN INSTRUMEN PENILAIAN SIKAP TOLERANSI DALAM PEMBELAJARAN TEMATIK SISWA KELAS IV SD." Jurnal Basicedu 3(1):194-99.

Watson, Amanda, Anna Timperio, Helen Brown, Keren Best, and Kylie D. Hesketh. 2017. "Effect of Classroom-Based Physical Activity Interventions on Academic and Physical Activity Outcomes: A Systematic Review and Meta-Analysis." International Journal of Behavioral Nutrition and Physical Activity 14(1):114. 
1083 Problem-Solving Method: The Effectiveness of the Pre-service Elementary Education Teacher Activeness in the Concept of Physics content-Bramianto Setiawan, Reza Rachmadtullah, Vina Iasha DOI: https://doi.org/10.31004/basicedu.v4i4.484 